\title{
Impact of internal remittance on households' use of bank services: evidence from Vietnam
}

\section{Impact of} remittances from internal migration

\author{
Thu Thi Hoai Nguyen \\ Vietnam Banking Academy, Hanoi, Vietnam \\ Hung Manh Le \\ Trade Union University, Hanoi, Vietnam \\ Le Quoc Hoi \\ National Economics University, Hanoi, Vietnam, and \\ Hang Thu Pham \\ Vietnam Banking Academy, Hanoi, Vietnam
}

\begin{abstract}
Purpose - This study estimates impact of remittances from internal migration on households' use of bank services in Vietnam.

Design/methodology/approach - This study uses data from the Vietnam Household Living Standards Survey and the two-stage least squares method (2SLS).

Findings - The results show that receiving internal remittance increases households' probability of having bank accounts and using card services. However, these impacts are different between rural and urban areas. Research limitations/implications - The results of this study reveal the useful role of internal remittance in increasing the probability of households using bank services, thereby enhancing financial inclusion in Vietnam.

Originality/value - Different from the previous studies, the purpose of this paper is to analyse the impact of internal remittance on the use of bank services in Vietnam at the household level. This paper targets internal migration because it is the main type of migration in Vietnam. Besides, to the best of the authors' knowledge, this research is the first one that compares the role of internal remittance on households' use of bank services in rural and urban areas in Vietnam.
\end{abstract}

Keywords Internal remittance, Bank services, Financial inclusion, Migration network, 2SLS, Vietnam

Paper type Research paper

\section{Introduction}

Using financial services, including bank services, is one of the key elements to promote financial inclusion. This is believed to be an important factor for the sustainable development goals of countries by increasing savings, investment, economic growth, poverty reduction and equality. United Nations emphasizes that, in order to achieve seven among the 17 sustainable development goals by 2030, financial inclusion is an important solution.

The relationship between remittances and the use of bank services can be developed from the theory of migration because remittance is often associated with migration. According to the New Economics of Labor Migration theory (NELM), migration is not a decision of a single

(C) Thu Thi Hoai Nguyen, Hung Manh Le, Le Quoc Hoi and Hang Thu Pham. Published in Journal of Economics, Finance and Administrative Science. Published by Emerald Publishing Limited. This article is published under the Creative Commons Attribution (CC BY 4.0) licence. Anyone may reproduce, distribute, translate and create derivative works of this article (for both commercial and non-commercial purposes), subject to full attribution to the original publication and authors. The full terms of this licence maybe seen at http://creativecommons.org/licences/by/4.0/legalcode 
JEFAS

27,53

individual but of a group of people, especially family members. Migration can be considered a household strategy. Therefore, migrants tend to send money home (Stark and Bloom, 1985; Stark and Taylor, 1991). This increases the demand for financial services, including services provided by banks. On the other hand, also according to NELM theory, the household member's decision to migrate and send money home reduces the risks that households may not be able to access financial and insurance markets when these markets become imperfect. This implies that remittance from migrants is an alternative for loans from the financial market, which may reduce demand for this market.

Internal migration is an important feature in many developing countries, including Vietnam. Coxhead et al. (2015) show that around $91 \%$ of migrants in Vietnam are internal migrants. As a result, internal remittance has become an income source for many households in Vietnam. According to the estimation results from Vietnam Household Living Standards Survey 2010-2016, the proportion of households that received internal remittance varied in the range of $25.2 \%$ (in 2016) to $33.3 \%$ (in 2012). Although many studies have explored the role of remittance in enhancing the use of bank services in many countries, this issue has not been fully studied in Vietnam. Moreover, the existing studies in the case of Vietnam only focused on international remittance, rather than remittances from internal migration. For example, Anh (2015) finds that international remittances had a positive, though not significant, impact on credit. UNCDF (2017) claims that international remittances increased the ability to use bank services, especially e-banking services for women in the Mekong region, including Vietnam.

Different from the previous studies, the purpose of this paper is to analyse the impact of internal remittance on the use of bank services in Vietnam at the household level. This paper targets internal migration because it is the main type of migration in Vietnam. Moreover, to the best of our knowledge, this research is the first one that compares the role of internal remittance on households' use of bank services in rural and urban areas in Vietnam. Besides, based on the estimation results, some policy implications are drawn to enhance households' use of bank services.

The next content of the paper has the following sections: section 2 reviews the relevant studies; section 3 presents data and methodology; section 4 shows the results; some discussions on the results are in section 5; and the sixth section reports the conclusions.

\section{Literature review}

Migration theories mainly focus on explaining individual migration decisions at different levels. Among these theories, the NELM is notable because it does not stop at explaining the reasons for migration but also provides a basis for analysing the effects of migration. According to NELM, migration is a part of households' strategy of allocating scarce resources. Therefore, migrants continue maintaining close relationships with their families in the destinations. One of the manifestations of this relationship is sending money home (Stark and Bloom, 1985; Stark and Taylor, 1991). This theory implies that migrants and their families will have demand for money transfer/receipt services and other financial services, including those provided by banks.

There has been a lot of research on the impact of remittances on the use of bank services in the sense that this is representative of financial inclusion. The studies reviewed in this paper focus primarily on the impact of remittances on households' use of bank services. Many studies reported the positive impact of remittances on the ability to access and use bank services at the household level. Receiving remittance increases households' demand for bank services such as account opening, money transfer, savings and so on. Quartey et al. (2019) use treatment effect estimators and a probit model to examine the link between remittances and households' probability of saving in Ghana. The results show that receiving remittances has 
a significant effect on the propensity to save households. However, in comparison to international remittances, the impact of receiving internal remittances on the probability of a households' saving is weaker. Salahuddin et al. (2021) also investigate the effects of remittances on households' savings behaviour. This study finds out that international remittances encourage households in Bangladesh to save in many forms, such as opening savings accounts, deposit pension schemes and savings at home. Aga and Peria (2014) analyse the impacts of receiving remittances on a households' probability to open bank accounts in Burkina Faso, Kenya, Nigeria, Senegal and Uganda. Results from linear probability model (LPM) and instrument variable (IV) regression show that international remittances might increase the households' probability to open bank accounts in all these five countries. Ajefu and Ogebe (2019) use data from migration surveys and households' deposit accounts to assess the impact of remittances on financial inclusion in Nigeria. In this study, the migration network effect is used as an IV to deal with the endogenous problem. Based on IV estimation, the study concludes that receiving remittances from migrants has increased the probability to use financial services in the formal sector such as having accounts opened at banks or using Internet/mobile banking. Anzoátegui et al. (2014) use household-level data to examine the impact of remittances on savings accounts and households' loans in El Salvador. The results show that remittances might increase demand for savings products in the formal financial sector. Ambrosius and Cuecuecha (2016) explore the impact of remittances on the use of formal and informal financial services in Mexico. Also, the results present a positive impact from remittances on the ownership of bank accounts of households. Yamada et al. (2021) use household-level data in rural areas in the Philippines to analyse the impact of international remittance on financial inclusion. The results show that remittance has positive and significant effects on having and using bank/microfinance accounts of the households. In the context of the COVID-19 pandemic, a decrease in inflow remittances caused by the COVID-19 crisis may have negative effects on financial inclusion in the Philippines.

Internal remittance affects households' use of bank services like opening accounts directly. Besides, receiving internal remittance via banks helps households to improve understanding of financial services, so increases the probability of using other bank services, including the use of card services. Watson (2009) shows that 30\% of customers transferring and receiving remittances became customers in other bank services.

In contrast, some studies show that receiving remittance negatively affects households' use of bank services. The reason here is that remittances may become a substitute for the loan provided by banks, so it decreases households' demand for bank services. Shrestha and Joshi (2018) use household-level data to analyse the impact of international remittance on the access to and use of formal financial services in Nepal. The estimation results from a probit regression suggested that remittances might reduce the need for both savings accounts and households' credit from the formal financial sector. Using panel data at the household level in Mexico, Ambrosius and Cuecuecha (2013) report that remittances from migrants were an alternative for loans when families have health-related shocks. In other words, remittances from migrants have met urgent financial needs and reduced the dependence of households on loans, even in the formal sector. Ambrosius and Cuecuecha (2016) examine the impact of remittances on financial inclusion in Mexico, especially using formal and informal financial services. Although the results support the positive role of remittances in households' ownership of savings/deposit accounts, the relationship between receiving remittances and the ability to borrow money in the formal financial sector has not been found. This study argues that it is more likely that informal financial institutions are willing to lend to receiving remittance households, whereas the formal financial sector cannot meet the needs of these households except providing savings accounts.
Impact of remittances from internal migration 
JEFAS

27,53

142

Studies on the impact of remittances from migration to the households' use of bank services in Vietnam have not been conducted much. Some studies made by Anh (2015) or UNCDF (2017) can be mentioned. Anh (2015) examines the impact of international remittance on financial development at a national level. Using a vector auto-regression model, this study shows that remittances have a slight effect on increasing the number of deposit accounts at banks. Meanwhile, the demand for credit declined, possibly due to the inflow of remittances. Although UNCDF (2017) focuses on gender equality in accessing financial services, the results also indicate that international remittance is an important factor to promote the accessibility and use of financial services for women, especially via digital channels.

Most previous studies focus on how international remittance affects financial inclusion in receiving countries. In the case of Vietnam, especially, it has no research on internal remittance and financial inclusion while internal migration is the main migration flow. Different from existing studies in Vietnam, this study was designed to estimate the impact of internal remittance on households' use of bank services. Furthermore, this study continues to separately estimate the impact of internal remittance on households' use of banking services for rural and urban areas because this impact may vary between these areas. The reason here is that emigrating from a rural area to find work and improve income is the main trend in internal migration in Vietnam (Le and Nguyen, 2019). Hence, remittance is an important source of rural households' income and migrants tend to remit more often. Meanwhile, compared to an urban area, the percentage of households using bank services in a rural area is much lower. Based on the empirical results, some conclusions and policy implications will be proposed to enhance the households' use of bank services from the internal remittance. Salcedo (2021) suggests that the discussion of policy should be encouraged in research, so these policy implications are expected to become another contribution of this study.

\section{Method}

\subsection{Data collection}

This study uses data from the Vietnam Household Living Standards Survey (2016). This survey was conducted by the General Statistics Office of Vietnam (GSO) with technical support from the World Bank to assess living standards at national, regional and provincial level. The income-expenditure sample VHLSS (2016) includes 9,399 households and covers all 63 provinces in Vietnam. It provides information on households' living areas, household characteristics such as the number of family members, genders, characteristics of heads of households, households' income and income sources as well as households' expenditure. When surveying households' income sources, information about whether a household receiving internal remittance or not can be obtained. Furthermore, the survey provides information on bank accounts ownership and whether households use card services such as ATM cards, credit cards or not. After dropping missing values, the number of observations in this study is 4,071. Apart from this data set, the data of the 2016 Enterprise Survey is used in combination with GSO data to estimate the density of banks.

\subsection{Econometric estimations and variables}

Based on the studies by Ajefu and Ogebe (2019) and Shrestha and Joshi (2018), this paper uses the following estimation model to assess the impact of internal remittances on the probability of households using bank services:

$$
Y_{i}=\alpha+\text { Bremit }_{i}+X_{i} \gamma+\varepsilon_{i}
$$

In the above equation:

$i$ is the household ID.

$Y$ is a dummy variable that is represented by two binary variables as: 
(1) (Y1) Whether household has deposit accounts or savings accounts at banks (denoted by $a c c): a c c=1$ if the household has deposit accounts or savings accounts at banks and 0 otherwise.

(2) (Y2) Whether the household has members who use bank services such as ATM or credit card (denoted by card): card $=1$ if the household has members who use ATM/ credit card and 0 otherwise.

The definition and measurement of all independent variables in the model is presented in Table 1 . The variable of interest in the model (1) is remit. This is a binary variable that reflects whether the household has received remittance from internal migration or not. If the household receives remittance from internal migration: remit $=1$; if not, then remit $=0$.

$X$ is a vector of control variables in the model, including household characteristics such as urban or rural living areas, household size, the percentage of dependents in the household (the percentage of children under 15 years old and the elderly over 60 years old in the household) and characteristics of household heads such as gender and education level. Because wealth also affects the use of financial services, expenditure per capita of the household is included as a control variable in the model (natural logarithm is taken). Household economic activities may also affect the use of financial services; therefore, a binary variable reflecting whether the household only has income from agriculture or not is added to the model. The density of bank branches in the province which may also affect the use of financial services is estimated by the number of bank branches in 1,000 hectares of residential land of the province.

$\alpha, \beta, \gamma$ are the parameters that need estimate in the model.

$\varepsilon$ is the error term.

\subsection{Analytical procedures}

Although some common methods, such as logit or probit regression, can be applied in a model with the binary dependent variable, the results from these techniques may be biased because of endogeneity. In model (1), the households' use of bank services may reversely

\begin{tabular}{|c|c|c|c|c|c|}
\hline Variable & Definition and measurement & Obs & Mean & $\begin{array}{l}\text { Std. } \\
\text { Dev. }\end{array}$ & $\begin{array}{l}\text { Expected } \\
\text { sign }\end{array}$ \\
\hline Remit & $\begin{array}{l}\text { Household receiving remittances from internal } \\
\text { migration }(\text { Yes }=1, \text { No }=0)\end{array}$ & 4,071 & 0.2524 & 0.4343 & + \\
\hline Hhsize & Number of households members & 4,071 & 3.7843 & 1.5553 & + \\
\hline Rdepend & $\begin{array}{l}\text { Percentage of children under } 15 \text { years old and the } \\
\text { elderly over } 60 \text { years old in the household }\end{array}$ & 4,071 & 0.3585 & 0.2973 & - \\
\hline Rfemale & Percentage of women in the household & 4,071 & 0.5237 & 0.2059 & \pm \\
\hline Lpcexp & $\begin{array}{l}\text { Natural logarithm of households' average annual } \\
\text { expenditure per capita (VND1,000) }\end{array}$ & 4,071 & 10.2531 & 0.6417 & + \\
\hline Agr & $\begin{array}{l}\text { Household having income only from agriculture } \\
(\text { Yes }=1, \text { No }=0)\end{array}$ & 4,071 & 0.2144 & 0.4105 & - \\
\hline edu_head & Number of schooling years of the household head & 4,071 & 1.9833 & 2.1868 & + \\
\hline gen_head & Gender of household head $($ Male $=1$, Female $=0$ ) & 4,071 & 0.7551 & 0.4301 & \pm \\
\hline Dbank & $\begin{array}{l}\text { Number of bank branches in a 1,000-ha residential } \\
\text { land of the province }\end{array}$ & 4,071 & 0.00165 & 0.00162 & + \\
\hline Urban & Household living in urban areas $(\mathrm{Yes}=1$, No $=0$ ) & 4,071 & 0.3007 & 0.4586 & + \\
\hline Acc & $\begin{array}{l}\text { Household having bank account(s) or savings } \\
\text { account(s) } \\
\left(\text { Yes }=1, \mathrm{No}_{1}=0\right)\end{array}$ & 4,071 & 0.3164 & 0.4651 & \\
\hline Card & $\begin{array}{l}\text { Household using ATM/credit card(s) (Yes }=1 \text {, } \\
\text { No }=0 \text { ) }\end{array}$ & 4,071 & 0.2584 & 0.4378 & \\
\hline
\end{tabular}

Source(s): Authors' estimation from VHLSS (2016)

Table 1 . Variable definition and measurement 
JEFAS

27,53

144

affect the probability of receiving remittance because it makes households receive remittance more conveniently. The impact of access to financial services on households receiving remittances has been investigated in some research, such as Munyegera and Matsumoto (2016) and Twumasi Baffour et al. (2021). To deal with the potential endogeneity problem, this study uses a two-stage least squares method (2SLS) to estimate model (1). In this method, an LPM is used for each step for some main reasons: first, the LPM does not require the errors in the first regression must satisfy any property of a correctly specified model. Second, the use of a control function requires the endogenous variable to be a continuous variable (while the endogenous variable in this study is a binary variable). Third, to consider the causal effect, the 2SLS technique can still be used in case both endogenous and dependent variables are binary variables (Angrist, 2001).

In the 2SLS method, the variable remit is instrumented by the proportion of households receiving internal remittances and the average amount of internal remittance received by households in a province. These IVs are known as the migration network effects (Ajefu and Ogebe, 2019; Shrestha and Joshi, 2018). Migration networks are the interpersonal relationships that link migrants, former migrants and non-migrants in their original area and destination through kinship, friendship or compatriots. Migration network theory suggests that the migration cost of the first migrant is very high. However, as the number of migrants increases, the growing migration network gradually reduces the migration costs of later migrants. The higher the number of migrants, the more extensive the migration network and the easier the migration will be (Massey et al., 1993). Besides, migration networks constitute a form of social capital that migrants can use to access employment in the destination, making migrants get higher benefits from migration. Therefore, the probability of a household receiving remittance is related to the emigration situation of the area in which the household resides.

Although migration network theory is often known as a theory of international migration, it can still be applied to explaining internal migration (Otoiu, 2014). In fact, some recent studies have also shown that migration network is a factor affecting internal migration in the examined countries, such as Pitoski et al. (2021) and Piras (2020). In Vietnam, the migration network is also one of the factors that promote internal migration (Coxhead et al., 2015; Dang et al., 2003).

From the arguments based on the migration theory and the context of internal migration in Vietnam, the migration network is chosen as an IV for the remit variable. Migration network can satisfy properties of an IV: the migrant network is positively correlated with receiving remittance of the household. Here, it is assumed that the migration network does not directly affect the dependent variable, which is the probability of households using bank services.

Some post estimation tests are also performed after using a 2SLS method, including the test of endogeneity to check whether the endogenous variable in the model is in fact exogenous. The null hypothesis in this test is the tested exogenous variable; the test of overidentifying restrictions. In this test, $\mathrm{H}_{0}$ hypothesis is that the IVs are valid; and the strength of the IVs will be checked via first-stage regression statistics.

\section{Results}

\subsection{Statistical analysis}

This section provides an overview of households' use of bank services and internal remittances that are estimated from the Vietnam Household Living Standards Survey 2016. As depicted in Table 2, generally the percentage of households having bank accounts and using card services (ATM and credit cards) is lower than that of households not using these services. In particular, the number of households without bank accounts or bank cards 
surpasses the number of households using them in a rural area. Specifically, nearly $79 \%$ of households do not have an account or savings account at banks, and up to $84.6 \%$ do not use ATMs or credit cards in this area.

While there is a significant disparity in the proportion of households using bank services and that of those without the services in a rural area, the figures in urban areas are not much different. It is notable that in an urban area the percentage of households that have accounts at banks is even higher than the percentage of households that do not have any accounts (nearly 5 percentage points). This may stem from the convenience of using card services in an urban area where ATM systems are often more developed and card payments are easier than in rural areas.

It can be seen from Table 3 that more than a quarter of households in Vietnam received internal remittance in 2016.

In particular, the proportion of households in rural areas receiving internal remittance was $27.4 \%$, higher than in urban areas $(23.6 \%)$. Regarding the volume of internal remittance, each household received nearly VND10.6m (about USD485) on average. Although the value of remittance was not much, it accounted for $9.4 \%$ of the households' income. The amount received by rural households (approximately VND9.7m) was lower than that of urban households (approximately VND12.9m). Because the average of households' income was small in a rural area, internal remittance contributed to households' income is more high in a rural area in comparison with an urban area (9.6\% versus $7.5 \%)$.

Statistics from VHLSS (2016) show that the percentage of households using banking services in Vietnam is still low, especially in a rural area. Regarding the receipt of internal remittance, rural area has a higher proportion of households receiving remittance and the contribution of remittance to households' income is also higher than that of urban households.

\subsection{Econometric analysis}

Table 4 indicates the estimation results of model (1). In the 2SLS method, the remittance variable is instrumented by the proportion of households that receive internal remittance and the average amount of internal remittance received by households in provinces.

\begin{tabular}{lcccccc}
\hline & $\begin{array}{c}\text { \% not having } \\
\text { account }\end{array}$ & $\begin{array}{c}\text { \% having } \\
\text { account }\end{array}$ & Total & $\begin{array}{c}\text { \% not using ATM/ } \\
\text { credit card }\end{array}$ & $\begin{array}{c}\text { \% using ATM/ } \\
\text { credit card }\end{array}$ & $\begin{array}{c}\text { Total } \\
(\%)\end{array}$ \\
\hline All & 68.3 & 31.7 & 100 & 74.2 & 25.8 & 100 \\
Urban & 47.6 & 52.4 & 100 & 52.9 & 47.1 & 100 \\
Rural & 78.8 & 21.2 & 100 & 84.6 & 15.4 & 100
\end{tabular}

Source(s): Authors' estimation from VHLSS (2016)

\section{Impact of remittances from internal migration}

\begin{tabular}{lccccc}
\hline & $\begin{array}{c}\text { \% receiving } \\
\text { internal } \\
\text { remittance }\end{array}$ & $\begin{array}{c}\text { \% not receiving } \\
\text { internal remittance }\end{array}$ & $\begin{array}{c}\text { Total } \\
(\%)\end{array}$ & $\begin{array}{c}\text { Internal remittance } \\
\text { amount (VND1,000) }\end{array}$ & $\begin{array}{c}\text { Share of internal } \\
\text { remittance in total } \\
\text { income }(\%)\end{array}$ \\
\hline All & 25.2 & 74.8 & 100 & 10,597 & 9.4 \\
Urban & 23.6 & 76.4 & 100 & 12,916 & 7.5 \\
Rural & 27.4 & 72.6 & 100 & 9,688 & 9.6
\end{tabular}

Note(s): Internal remittance amount and share of internal remittance in total income are calculated for households receiving internal remittance

Source(s): Authors' estimation from VHLSS (2016)
Table 2.

Percentage of households' use of bank services by area
Table 3. Percentage of households that received internal remittance and proportion of internal remittance in total household income 


\begin{tabular}{|c|c|c|c|}
\hline \multirow{6}{*}{$\begin{array}{l}\text { JEFAS } \\
27,53\end{array}$} & \multicolumn{2}{|r|}{$\mathrm{Y} 1$ (acc) } & Y2 (card) \\
\hline & remit & $0.0914 * * *(0.0298)$ & $0.0909 * * * *(0.0313)$ \\
\hline & hhsize & $0.0578 * * *(0.00421)$ & $0.0831^{* * * *}(0.00435)$ \\
\hline & rdepend & $0.00260(0.0201)$ & $-0.129 * * *(0.0203)$ \\
\hline & rfemale & $-0.0477(0.0309)$ & $-0.0365(0.0316)$ \\
\hline & lpcexp & $0.243 * * *(0.0118)$ & 0.225 *** $(0.0120)$ \\
\hline 146 & agr & $-0.00714(0.0135)$ & $-0.0433 * * *(0.0143)$ \\
\hline \multirow{12}{*}{$\begin{array}{l}\text { Table } 4 \text {. } \\
\text { Impact of internal } \\
\text { remittance on } \\
\text { households' use of } \\
\text { bank services (2SLS } \\
\text { method) }\end{array}$} & edu_head & $0.0287 * * *(0.00346)$ & 0.0440 *** $(0.00318)$ \\
\hline & gen_head & $-0.0584 * * *(0.0163)$ & $-0.0694 * * *(0.0167)$ \\
\hline & dbank & $5.869(4.030)$ & $-5.555(4.065)$ \\
\hline & urban & $0.127 * * *(0.0169)$ & $0.0960 * * *(0.0169)$ \\
\hline & Constant & $-2.558 * * *(0.126)$ & $-2.359 * * *(0.128)$ \\
\hline & Observations & 4,071 & 4,071 \\
\hline & $R$-squared & 0.265 & 0.292 \\
\hline & Durbin & $p=0.0086$ & $p=0.0022$ \\
\hline & Wu-Hausman & $p=0.0084$ & $p=0.0022$ \\
\hline & Sargan & $p=0.4800$ & $p=0.3154$ \\
\hline & First-stage & $p=0.0000$ & $p=0.0000$ \\
\hline & \multicolumn{3}{|c|}{$\begin{array}{l}\text { Note(s): Robust standard errors in parentheses, } * * * p<0.01 \\
\text { Source(s): Authors' estimation from VHLSS (2016) }\end{array}$} \\
\hline
\end{tabular}

The estimation results show that the coefficients of the variable remit in the model with dependent variables acc and card are positive and statistically significant at a $1 \%$ level. Receiving remittances from internal migration increases the probability of households having bank accounts up to 9 percentage points and increased the likelihood of households to use an ATM/credit card to 9 percentage points. This is probably because receiving remittances increases households' income, and then, increases the demand for savings and using other bank services, including card services. These results are in line with Ajefu and Ogebe (2019) and seem to be inconsistent with Shrestha and Joshi (2018). However, it should be noticed that this study and Ajefu and Ogebe (2019) analyse the impact of internal remittance on households' use of bank services while Shrestha and Joshi (2018) examine international remittance. Moreover, the estimation results imply that migrants and their families may choose bank services to send and receive remittances. It is a positive signal in the case of Vietnam because some surveys revealed that using banking services just occupies a small portion among many options to remit home. For example, GSO and IOM (2012) survey 600 migrants in Hanoi and showed that although regarded as a safe way, money transfer services by banks were used by only over $13 \%$ of migrants. Meanwhile, most of the migrants brought money home by themselves, sent via shuttle buses or through friends. However, it should be noted that about half of migrants in the GSO and IOM survey worked in the informal and unskilled sector, so the results may not be highly representative for internal migrants in Vietnam.

Concerning the control variables, the estimation results show that many household characteristics affect the households' probability of using bank services. For example, the increase in the number of household members will raise the probability of households using bank services. A household with a higher dependent rate will have a lower probability of using card services. The reason here is that card services are usually used by working-age adults. These results were also found in Shrestha and Joshi (2018). In addition, this study finds out that the wealth of households is an important factor that drives households to use bank services. As expected, the higher the households' expenditure per capita, the higher the probability to use bank services. In addition, if a household has only an income source from agricultural activities, it is less likely to use bank services, especially the use of card services. 
The characteristics of the household head also affect the probability of the households' use of bank services. For example, the educational level of the household head has a positive effect on the households' use of bank services. Besides, the estimation results interestingly report that the probability of households using bank services will increase if the household head is female. This result is in line with Shrestha and Joshi (2018).

It can be seen that all of the above variables are determinants of demand for banking services. In model (1), bank density is a determinant of the supply-side. However, the coefficients of the variable dbank are not statistically significant. The results imply that household use of banking services may be more influenced by demand-side factors.

Outmigration from a rural area is the most popular migration flow in Vietnam, so rural area is likely to become the main receiving internal remittance area. However, the rate of using bank services is much lower in rural areas compared to urban areas. To have a further investigation of the impact of internal remittance on households' use of bank services, this study continues to consider this impact in urban and rural areas.

From the argument that the use of banking services can induce households to receive remittances easier and thereby increase the probability of households receiving remittances, this study proposes to use the 2SLS method to solve potential endogenous problems. Post estimation tests with a sample of rural households and national data confirm this argument. However, with the sample of urban households, the $p$ values in the Durbin and $\mathrm{Wu}$-Hausman statistics are greater than 0.05 , which means that the null hypothesis on exogenous variables is not rejected (the results are presented in Appendix). Hence, this study treats remit as an exogenous variable and uses an LPM to estimate model (1) in the sample of rural households. It is difficult to fully explain why remit is endogenous in a model with rural households and national data but not urban household data. However, it is possible to see from Tables 2 and 3 that the percentage of households that use bank services in a rural area is quite low in comparison to this figure in an urban area, which makes households that use bank services in the rural area more selective. In addition, the difficulties in infrastructure conditions in rural areas also make these households have some more advantages in receiving remittance than other households that do not use bank services (Hoang, 2020; Pham and Riedel, 2019). Besides, the number of households in the rural area accounts for approximately $70 \%$ of the households in the whole sample, which may be the reason why endogenous problems are still detected in the whole sample.

It can be seen from Table 5, internal remittance has positive and significant impacts on households' use of bank services in the sample of rural households [columns (2) and (4)], while these impacts are not significant in the sample of urban households. Other things equal, if a household in a rural area receives internal remittance, the probability of having deposit accounts increases 8 percentage points, and the probability that the household uses card services increases 11.2 percentage points.

The results imply that internal remittance induces rural households' demand for opening accounts and using card services. The reason here is that migrant members in rural households usually play an important role in generating income for the households, so they remit more often and have a high demand for financial services. In addition, estimation results from VHLSS (2016) show that around $79 \%$ of households in rural areas do not have any accounts at banks, whereas this number is approximately $47 \%$ in an urban area. The small coverage of bank services in a rural area may highlight the impact of internal remittance on households' use of banking services here. Moreover, financial activities that relate to remittance may improve rural households' knowledge and the use of other services provided by banks, as shown by the studies of Chami and Fullenkamp (2012) and Nyamongo et al. (2012). So, the impacts of internal remittance on increasing the probability of using bank services of households in a rural area, including having accounts at banks and using card services, are remarkable.
Impact of remittances from internal migration 


\begin{tabular}{|c|c|c|c|c|c|}
\hline \multirow{2}{*}{$\begin{array}{l}\text { JEFAS } \\
27,53\end{array}$} & & \multicolumn{2}{|c|}{$\mathrm{Y} 1$ (acc) } & \multicolumn{2}{|c|}{ Y2 (card) } \\
\hline & & Urban area (1) & Rural area (2) & Urban area (3) & Rural area (4) \\
\hline \multirow[b]{5}{*}{148} & Remit & $0.0232(0.034)$ & $0.0802 * * *(0.0307)$ & $0.0292(0.0322)$ & $0.112 * * *(0.0351)$ \\
\hline & Hhsize & $0.0694 * * *(0.00828)$ & $0.0524^{* * * *}(0.00488)$ & $0.0874 * * *(0.00844)$ & $0.0834 * * *(0.00514)$ \\
\hline & Rdepend & $-0.027(0.0431)$ & $0.0146(0.0217)$ & $-0.235^{* * *}(0.0394)$ & $-0.0812 * * *(0.0227)$ \\
\hline & Rfemale & $-0.026(0.0645)$ & $-0.0583 *(0.0339)$ & $-0.022(0.0634)$ & $-0.0448(0.0358)$ \\
\hline & Lpcexp & $0.287^{* * * *}(0.0224)$ & $0.221^{* * *}(0.0138)$ & $0.214^{* * * *}(0.0225)$ & $0.234 * * *(0.0140)$ \\
\hline \multirow{12}{*}{$\begin{array}{l}\text { Table } 5 \text {. } \\
\text { Impact of internal } \\
\text { remittance on }\end{array}$} & Agr & $-0.00876(0.0507)$ & $-0.00884(0.0137)$ & $-0.0788(0.0479)$ & $-0.0367 * *(0.0149)$ \\
\hline & edu_head & $0.0281 * * *(0.00488)$ & $0.0251 * * *(0.00537)$ & $0.0456 * * *(0.00419)$ & $0.0415 * * *(0.00521)$ \\
\hline & gen_head & $-0.041(0.0296)$ & $-0.0624 * * *(0.0191)$ & $-0.0208(0.0278)$ & $-0.0936 * * *(0.0210)$ \\
\hline & Dbank & $-6.618(9.257)$ & $9.818^{* *}(4.436)$ & 12.0291 (8.731) & $0.0624(0.605)$ \\
\hline & Constant & $-2.886 * * *(0.247)$ & $-2.306 * * *(0.148)$ & $-2.046^{* * * *}(0.247)$ & $-2.472 * * *(0.150)$ \\
\hline & Observations & 1,224 & 2,847 & 1,224 & 2,847 \\
\hline & $R$-squared & 0.225 & 0.146 & 0.287 & 0.19 \\
\hline & Durbin & & $p=0.0369$ & & $p=0.0025$ \\
\hline & $\mathrm{Wu}-$ & & $p=0.0363$ & & $p=0.0024$ \\
\hline & Hausman & & & & \\
\hline & Sargan & & $p=0.2065$ & & $p=0.1054$ \\
\hline & First-stage & & $p=0.0000$ & & $p=0.0000$ \\
\hline
\end{tabular}

households' use of $\quad$ Note(s): Robust standard errors in parentheses, $* * * p<0.01, * * p<0.05, * p<0.1$; Results in the column (2) and bank services by urban (4) are from the 2SLS method; results in the column (1) and (3) are from the LPM

and rural area $\quad$ Source(s): Authors' estimation from VHLSS (2016)

The results also show that the bank density has a positive impact on the probability of having bank accounts of rural households. Because the density of banks in a rural area is much lower than that in an urban area, an increase in bank density may induce a strong positive effect on the ability to access bank services of households. Hence, it has a positive impact on households' use of bank accounts in rural areas. Households' use of card services may not be affected by the density of banks directly because the use of these services requires the availability of some other machines like ATM or point of sale (POS) et cetera. Coefficients of other control variables such as the number of household members, per capita expenditure and the number of household heads' schooling years continue to be statistically significant. These results assert the role of these household characteristics in the use of banking services.

\section{Discussion}

\subsection{Theoretical implications}

Remittances are an integral aspect of not only international migration but also internal migration. Especially, analysing the roles of internal remittance in economic development is very important in developing countries like Vietnam because internal migration is usually the main form. Besides, migration network theory, a theory that is known as an international migration theory, is useful in studying internal migration issues.

\subsection{Policy implications}

Based on the estimation results, some policy implications are drawn. First, the impacts of internal remittances on the probability of households using bank services indicate that the use of bank services is greatly influenced by the demand for these services. Internal migrants and their families want to use banks as a channel for sending, receiving and saving money. Moreover, through these transactions, their understanding of other services provided by banks can be broadened. Thus, banks should pay more attention to internal migrants to explore their potential demand and provide appropriate products and services. 
Second, the education level of the household head has a positive role in increasing the households' use of bank services. While poor households are often associated with low education levels, they may not have much information on financial services, face many difficulties in accessing and using these services. To promote financial inclusion, financial institutions should raise public awareness of financial services and provide services with detailed information supports.

In third place, this study provides evidence that the gender of the household head affects the households' use of bank services. Although gender characteristics may influence the decision to use banking services, the use of banking services by women-headed households could be a female empowerment outcome of local women's associations in Vietnam. This result implies that governments and financial institutions need to pay more attention to gender characteristics and the role of women's associations in promoting financial inclusion.

Finally, rates of households' use of bank services are still low in rural areas, whereas receiving internal remittance increases the probability of households' use of banking services. Therefore, local governments in rural areas should have policies to attract more remittances and encourage the positive role of remittances in enhancing financial inclusion.

\subsection{Future research agenda}

This study focuses on the impact of internal remittance on households' use of banking services. It would be more interesting if both internal remittance and international remittance were analysed and compared. Besides, the volume of remittances may also affect the decision to use bank services of households. These issues are left for future studies.

\section{Conclusions}

Using data from the Vietnam Household Living Standards Survey 2016, this study explores the impact of internal remittance on households' use of bank services in Vietnam. The results from the 2SLS and the LPM indicate that internal remittance may enhance the probability of having bank accounts and using card services of households in Vietnam. However, these impacts vary by urban and rural areas. Receiving internal remittances increases the probability of owning accounts at banks and using ATM/credit cards of rural households while this study has not confirmed these effects in the urban area. This study also shows that some household characteristics such as household head's education level, number of household members and household living standards (e.g. household expenditure) affect a households' use of banking services. Interestingly, the gender of the household head is also a determinant of the households' decision on using bank accounts and card services, whereby, a female-headed household is more likely to use bank services. Hence, banks and government policies should pay more attention to these elements to increase demand for formal financial services.

\section{References}

Aga, G.A. and Peria, M.S.M. (2014), "International remittances and financial inclusion in Sub-Saharan Africa”, Policy Research Working Paper, Vol. 6991, available at: https://openknowledge. worldbank.org/handle/10986/19383.

Ajefu, J.B. and Ogebe, J.O. (2019), "Migrant remittances and financial inclusion among households in Nigeria", Oxford Development Studies, Vol. 47 No. 3, pp. 319-335.

Ambrosius, C. and Cuecuecha, A. (2013), "Are remittances a substitute for credit? Carrying the financial burden of health shocks in national and transnational households", World Development, Vol. 46, pp. 143-152. 
JEFAS 27,53
Ambrosius, C. and Cuecuecha, A. (2016), "Remittances and the use of formal and informal financial services”, World Development, Vol. 77, pp. 80-98.

Angrist, J.D. (2001), "Estimation of limited dependent variable models with dummy endogenous regressors: simple strategies for empirical practice", Journal of Business and Economic Statistics, Vol. 19 No. 1, pp. 2-28.

Anh, P.T.H. (2015), "Impact of remittances on financial development in Vietnam", Journal of Economic Development, Vol. 22 No. 3, pp. 46-58.

Anzoátegui, D., Demirgüç-Kunt, A. and Martínez Pería, M.S. (2014), "Remittances and financial inclusion: evidence from El Salvador", World Development, Vol. 54, pp. 338-349.

Chami, R. and Fullenkamp, C. (2012), "4. Workers' remittances and economic development: realities and possibilities", Maximising the Development Impact of Remittances, United Nations, pp. 30-38, available at: https:/unctad.org/system/files/official-document/ditctncd2011d8_en. pdf \#page $=45$.

Coxhead, I., Nguyen, C.V. and Vu, L.H. (2015), "Migration in Vietnam: new evidence from recent surveys”, World Bank: Vietnam Development Economics Discussion Papers, Vol. 2, doi:10.2139/ ssrn.2752834.

Dang, N.A., Tacoli, C. and Hoang, X.T. (2003), "Migration in Vietnam: a review of information on current trends and patterns, and their policy implications", Regional Conference on Migration, Development and Pro-Poor Policy Choices in Asia, Dhaka, Bangladesh, pp. 22-24.

GSO and IOM (2012), Gender and Remittances from Internal Migrants, Statistical Publishing House, Hanoi.

Hoang, Q.V. (2020), "Determinants of the result of new rural development program in Vietnam", Journal of Economics and Development, Vol. 22 No. 1, pp. 81-90, doi: 10.1108/JED-12-2019-0076.

Le, Q.H. and Nguyen, T.H.T. (2019), "The impact of internal migration on poverty reduction through changes in human capital and transformation in labor structure", Journal of Economics and Development, Vol. 19 No. 1, pp. 2-11.

Massey, D.S., Arango, J., Hugo, G., Kouaouci, A., Pellegrino, A. and Taylor, J.E. (1993), “Theories of international migration: a review and appraisal”, Population and Development Review, Vol. 19 No. 3, pp. 431-466, doi: 10.2307/2938462.

Munyegera, G.K. and Matsumoto, T. (2016), "Mobile money, remittances, and household welfare: panel evidence from rural Uganda", World Development, Vol. 79, pp. 127-137.

Nyamongo, E.M., Misati, R.N., Kipyegon, L. and Ndirangu, L. (2012), "Remittances, financial development and economic growth in Africa", Journal of Economics and Business, Vol. 64 No. 3, pp. 240-260.

Otoiu, A. (2014), "Getting your migration analysis together by integrating internal and international migration”, Procedia-Social and Behavioral Sciences, Vol. 149, pp. 685-690.

Pham, T.H. and Riedel, J. (2019), "Impacts of the sectoral composition of growth on poverty reduction in Vietnam", Journal of Economics and Development, Vol. 21 No. 2, pp. 213-222, doi: 10.1108/ JED-10-2019-0046.

Piras, R. (2020), "Internal migration in Italy: the role of migration networks", Italian Economic Journal, Vol. 6 No. 1, pp. 157-195.

Pitoski, D., Lampoltshammer, T.J. and Parycek, P. (2021), "Network analysis of internal migration in Austria”, Digital Government: Research and Practice, Vol. 2 No. 3, pp. 1-24.

Quartey, P., Ackah, C. and Lambon-Quayefio, M.P. (2019), "Inter-linkages between remittance and savings in Ghana”, International Journal of Social Economics, Vol. 46 No. 1, pp. 152-166, doi: 10. 1108/IJSE-12-2017-0618.

Salahuddin, S., Masud, M.M. and Kian Teng, K. (2021), "Remittances and households' savings behaviour in Bangladesh", Society and Business Review, Vol. 17 No. 1, pp. 120-140, doi: 10.1108/ SBR-08-2020-0104. 
Salcedo, N.U. (2021), "Editorial: Review and roadmap from the last 10 years (2010-2020)", Journal of Economics, Finance and Administrative Science, Vol. 26 No. 51, pp. 2-6, doi: 10.1108/JEFAS-06-2021-271.

Shrestha, S. and Joshi, N.K. (2018), Remittances and Financial Inclusion: Evidence from Nepal, New York University, Shanghai.

Stark, O. and Bloom, D.E. (1985), "The new economics of labor migration", The American Economic Review, Vol. 75 No. 2, pp. 173-178.

Stark, O. and Taylor, J.E. (1991), "Migration incentives, migration types: the role of relative deprivation”, The Economic Journal, Vol. 101 No. 408, pp. 1163-1178.

Twumasi Baffour, P., Abdul Rahaman, W. and Mohammed, I. (2021), "Impact of mobile money access on internal remittances, consumption expenditure and household welfare in Ghana", Journal of Economic and Administrative Sciences, Vol. 37 No. 3, pp. 337-354, doi: 10.1108/JEAS-042020-0045.

United Nations Capital Development Fund (2017), Remittances as a Driver of Women's Financial Inclusion, available at: https://www.uncdf.org/article/2173/remittances-as-a-driver-of-womensfinancial-inclusion-in-the-mekong-region (accessed 02 June 2019).

VHLSS (2016), Vietnam Household Living Standard Survey 2016, General Statistics Office, Vietnam.

Watson, G. (2009), "Linking remittances and access to finance", Global Remittances Working Group: G8 International Conference on Remittances, Rome.

Yamada, E., Shimizutani, S. and Murakami, E. (2021), "The COVID-19 pandemic, remittances and financial inclusion in the Philippines", Philippine Review of Economics, Vol. 57 No. 1, pp. 18-41.

Appendix

\begin{tabular}{lccccc}
\hline Variable & Obs & Mean & Std. Dev. & Min & Max \\
\hline Urban area & & & & & \\
card & 1,224 & 0.478 & 0.500 & 0 & 1 \\
acc & 1,224 & 0.532 & 0.499 & 0 & 1 \\
hhsize & 1,224 & 3.804 & 1.545 & 1 & 1 \\
rdepend & 1,224 & 0.351 & 0.292 & 0 & 1 \\
rfemale & 1,224 & 0.532 & 0.207 & 0 & 13.487 \\
lpcexp & 1,224 & 10.655 & 0.646 & 8.248 & 1 \\
agr & 1,224 & 0.067 & 0.250 & 0 & 1 \\
edu_head & 1,224 & 2.947 & 2.948 & 0 & \\
gen_head & 1,224 & 0.667 & 0.472 & 0 & 1 \\
Rural area & & & & & 1 \\
card & 2,847 & 0.164 & 0.370 & 0 & 1 \\
acc & 2,847 & 0.224 & 0.417 & 0 & 1 \\
hhsize & 2,847 & 3.776 & 1.560 & 1 & 1 \\
rdepend & 2,847 & 0.362 & 0.300 & 0 & \\
rfemale & 2,847 & 0.520 & 0.205 & 0 & \\
lpcexp & 2,847 & 10.080 & 0.557 & 7.982 & Summary of variables \\
agr & 2,847 & 0.278 & 0.448 & 0 & \\
edu_head & 2,847 & 1.569 & 1.591 & 0 & \\
gen_head & 2,847 & 0.793 & 0.405 & 0 & \\
\hline
\end{tabular}

Impact of remittances from internal migration 
JEFAS

27,53

152

Table A2.

Correlation matrix

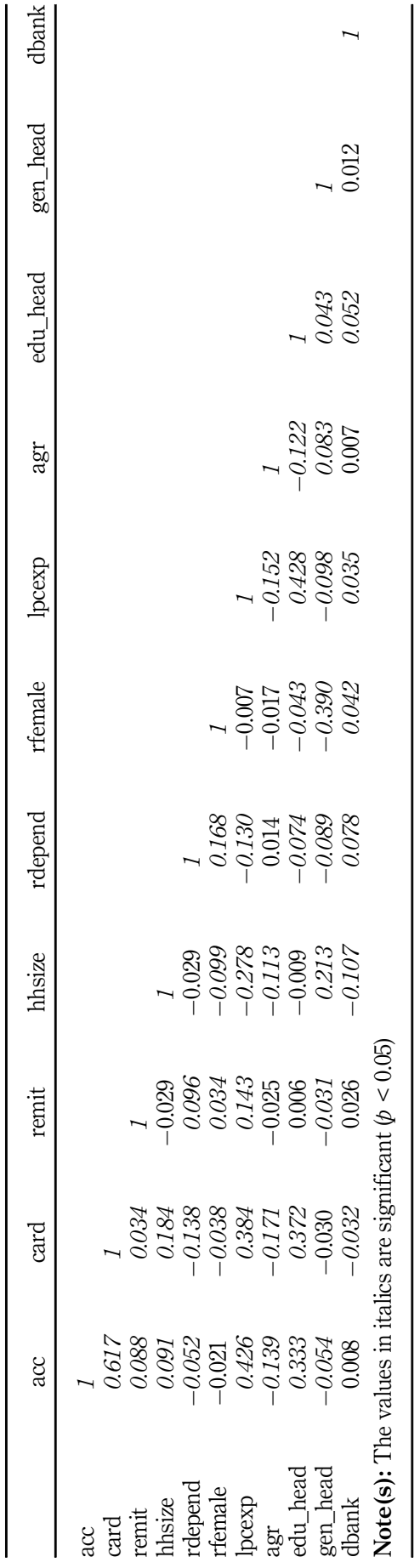




\begin{tabular}{|c|c|c|c|}
\hline & $\mathrm{Y} 1$ (acc) & Y2 (card) & Impac \\
\hline Remit & $0.131 *(0.0686)$ & $0.0288(0.0648)$ & from internal \\
\hline Hhsize & $0.0694 * * *(0.0083)$ & $0.0873^{* * *}(0.00843)$ & \\
\hline rdepend & $-0.0468(0.0452)$ & $-0.246^{* * *}(0.0408)$ & migration \\
\hline rfemale & $-0.033(0.0647)$ & $-0.0258(0.0634)$ & \\
\hline lpcexp & 0.286 **** $(0.0226)$ & $0.214^{* * *}(0.0225)$ & \\
\hline agr & $-0.00713(0.05)$ & $-0.078(0.0475)$ & 153 \\
\hline edu_head & $0.0287 * * *(0.00489)$ & $0.0460 * * *(0.00419)$ & \\
\hline gen_head & $-0.0451(0.0297)$ & $-0.023(0.0279)$ & \\
\hline dbank & $-7.685(9.305)$ & $12.0304(8.732)$ & \\
\hline Constant & $-2.956 * * *(0.248)$ & $-2.084 * * *(0.248)$ & \\
\hline Observations & 1,224 & 1,224 & Table A3. \\
\hline$R$-squared & 0.219 & 0.285 & Estimation results of \\
\hline Durbin & $p=0.0705$ & $p=0.3084$ & model (1) on the sample \\
\hline Wu-Hausman & $p=0.0713$ & $p=0.3115$ & (results from 2SLS \\
\hline \multirow{2}{*}{\multicolumn{3}{|c|}{$\begin{array}{l}\text { Note(s): Robust standard errors in parentheses, } * * * p<0.01,{ }^{*} p<0.1 \\
\text { Source(s): Authors' estimation from VHLSS (2016) }\end{array}$}} & method and \\
\hline & & & endogeneity test) \\
\hline
\end{tabular}

\section{Corresponding author}

Hung Manh Le can be contacted at: hunglm@dhcd.edu.vn

For instructions on how to order reprints of this article, please visit our website:

www.emeraldgrouppublishing.com/licensing/reprints.htm

Or contact us for further details: permissions@emeraldinsight.com 